Article

\title{
Sustainable Diesel from Pyrolysis of Unsaturated Fatty Acid Basic Soaps: The Effect of Temperature on Yield and Product Composition
}

\author{
Endar Puspawiningtiyas ${ }^{1,2}$, Oki Muraza ${ }^{3}$, Hary Devianto ${ }^{1}$, Meiti Pratiwi ${ }^{1,4}$, Subagjo ${ }^{1}$, Tirto Prakoso ${ }^{1,4}(\mathbb{D}$, \\ Krisnawan ${ }^{1}$, Usamah Zaki ${ }^{1}$, Lidya Elizabeth ${ }^{5}$, Tatang H. Soerawidjaja ${ }^{1,4}$, Yohanes Andre Situmorang ${ }^{4}$ \\ and Antonius Indarto $1,4, *$ (D)
}

Citation: Puspawiningtiyas, E.;

Muraza, O.; Devianto, H.; Pratiwi, M.;

Subagjo; Prakoso, T.; Krisnawan;

Zaki, U.; Elizabeth, L.; Soerawidjaja,

T.H.; et al. Sustainable Diesel from

Pyrolysis of Unsaturated Fatty Acid

Basic Soaps: The Effect of

Temperature on Yield and Product

Composition. Molecules 2022, 27, 667.

https://doi.org/10.3390/

molecules 27030667

Academic Editor: Adele Papetti

Received: 30 November 2021

Accepted: 7 January 2022

Published: 20 January 2022

Publisher's Note: MDPI stays neutral with regard to jurisdictional claims in published maps and institutional affiliations.

Copyright: (C) 2022 by the authors. Licensee MDPI, Basel, Switzerland. This article is an open access article distributed under the terms and conditions of the Creative Commons Attribution (CC BY) license (https:// creativecommons.org/licenses/by/ $4.0 /)$.
1 Department of Chemical Engineering, Institut Teknologi Bandung, Ganesha Street No. 10, Bandung 40132, Indonesia; endartiyas@yahoo.com (E.P.); hardev@che.itb.ac.id (H.D.); mei@che.itb.ac.id (M.P.); subagjo@che.itb.ac.id (S.); tirto@che.itb.ac.id (T.P.); krisnawanj@gmail.com (K.); usamah.zaki96@gmail.com (U.Z.); thsoerawidjaja@gmail.com (T.H.S.)

2 Department of Chemical Engineering, Universitas Muhammadiyah Purwokerto, Purwokerto 53182, Indonesia

3 Research \& Technology Innovation, Pertamina, Sopo Del Building, 51st Fl. Jl. Mega Kuningan Barat, Jakarta Pusat 12950, Indonesia; oki.muraza@pertamina.com

4 Departement of Bioenergy Engineering and Chemurgy, Institut Teknologi Bandung, Jalan Let. Jen. Purn. Dr. (HC). Mashudi No. 1 Sumedang, Kota Bandung 45363, Indonesia; yohanes.andrest@gmail.com

5 Department of Chemical Engineering, Politeknik Negeri Bandung, Gegerkalong Hilir Street, Bandung 40559, Indonesia; lidya.elizbth@gmail.com

* Correspondence: indarto_antonius@yahoo.com

\begin{abstract}
The production of sustainable diesel without hydrogen addition remains a challenge for low-cost fuel production. In this work, the pyrolysis of unsaturated fatty acid (UFA) basic soaps was studied for the production sustainable diesel (bio-hydrocarbons). UFAs were obtained from palm fatty acids distillate (PFAD), which was purified by the fractional crystallization method. Metal hydroxides were used to make basic soap composed of a $\mathrm{Ca}, \mathrm{Mg}$, and $\mathrm{Zn}$ mixture with particular composition. The pyrolysis reactions were carried out in a batch reactor at atmospheric pressure and various temperatures from 375 to $475^{\circ} \mathrm{C}$. The liquid products were obtained with the best yield $\left(58.35 \%\right.$ ) at $425{ }^{\circ} \mathrm{C}$ and yield of diesel fraction $53.4 \%$. The fatty acids were not detected in the pyrolysis liquid product. The gas product consisted of carbon dioxide and methane. The liquid products were a mixture of hydrocarbon with carbon chains in the range of $C_{7}$ and $C_{20}$ containing n-alkane, alkene, and iso-alkane.
\end{abstract}

Keywords: pyrolysis; unsaturated fatty acid; basic soap; metal hydroxide; biohydrocarbon

\section{Introduction}

Increased energy demand and issues related to environmental concerns constitute a strong reason many countries have chosen to use alternative and renewable energy technologies. Biohydrocarbon or liquid hydrocarbon are renewable fuels derived from any material originating from biological matters [1], including biomass [2], lignocellulose [3], triglycerides, or fatty acids [4,5]. There are many reasons for the strong interest in biofuels, among others their easy availability from common biomass. Biofuels represent a carbon dioxide cycle in combustion. They have considerable environmentally friendly potential, and they are biodegradable and contribute to sustainability [6]. Nowadays, the main processes used to obtain biofuels from vegetable oils are transesterification and thermal cracking (pyrolysis) or thermal-catalytic cracking (catalytic pyrolysis) [7]. Biodiesel, a promising biofuel, is made from renewable biological sources, such as vegetable oils and animal fats, by chemically reacting oil or fat with an alcohol (transesterification) in the presence of a homogeneous and heterogeneous catalysts [8]. Biodiesel is renewable, 
biodegradable, nontoxic, and produces low emission during combustion [9]. However, there are some disadvantages of biodiesel, as listed by Baladincz et al. [10], such as (a) high unsaturated bond content of fatty acids (causing bad thermal oxidation, and thus instability); (b) relatively high hygroscopic property; (c) reactive $\mathrm{OH}$-group cause corrosion of metals; (d) relatively lower calorific value which causes high fuel consumption, and (e) unfavorable cold flow properties. According to Solymosi et al. [11], biodiesel, as one of the first generation biofuels, remains proportionally limited when used as a fuel due to the properties of this compound. According to [12], biodiesel contains about $10 \%$ oxygen by weight.

Among thermochemical processes, pyrolysis has received increased interest since the process conditions can be optimized to maximize the production of chars, liquids, or gases [13]. Thermal pyrolysis operates at $700-1000{ }^{\circ} \mathrm{C}$ and produces mostly gaseous products containing straight-chain hydrocarbon fuels, according to Araújoet et al. [7]. The pyrolysis of fatty acids or triglycerides into biofuel can be achieved from different sources of fatty acids or triglycerides, including soybean (Glycine max) by Junming et al. [14], sunflower by Yigezu and Muthukumar [15], jatropha oil by Biswas et al. [16], waste shipping oil by Wan Mahari [17], trilaurin and trimyristin by Chiappero et al. [18], cotton seed oil by Li et al. [19], and Canola by Idem et al. [20].

According to Demirbaş [21], the soap obtained by the saponification of vegetable oils can produce hydrocarbon with upper yield at higher temperatures. The saponification of triglycerides prior to the pyrolysis process is proposed as a step towards obtaining compositions of liquid product similar to diesel fuel. The liquid product yield of soap pyrolysis was higher than triglyceride pyrolysis. In addition, it contains less oxygenated compounds according to Lappi and Alén [22]. There are advantages of soap pyrolysis products rather than triglycerides, including lower acid value [23], lack of polymerization, less sludge formation, and lower viscosity, according to Hiebert [24]. Furthermore, it was more stable and demonstrated less tendency to form wax, as reported by Joonwichien et al. [25].

Most of the previous researches used soap pyrolysis to produce hydrocarbon according to Kaisha [26]. That report considered the pyrolysis reaction mechanism of stoichiometric and basic sodium soap. It showed that, at pyrolysis temperature, stoichiometric sodium soap produced not only short chain hydrocarbon, but also ketone and aldehyde, whereas the pyrolysis of basic sodium soap produced only hydrocarbon. This mechanism was supported by Hites and Biemann [27], who reported that the liquid product from pyrolysis of calcium decanoic stoichiometric soap usually contained ketone compounds and carbonyl group. The compounds disappeared at the upper temperature of $500{ }^{\circ} \mathrm{C}$. This showed that the basic is better than the stoichiometric soap to produce a liquid product free from oxygenated compounds. Other reviews within the same field include those by Hiebert et al. [24] and Kufeld et al. [28]. Most of the works used single metal, while there are still a few references that reported the use of two or three metals to obtain hydrocarbon via the pyrolysis of basic soap. In addition, the decarboxylation reaction occurred when divalent metal base soaps, such as calcium and magnesium, were heated without air under atmospheric pressure, in the temperature range $200-400{ }^{\circ} \mathrm{C}$, producing hydrocarbon, according to Markley et al. [29].

The production of hydrocarbons via pyrolysis of the basic soap was investigated in this research. Figure 1 shows the technology of basic soap pyrolysis in the scope of the biofuel production from vegetables oils. The figure shows oils / fats or fatty acids as the raw material for making hydrocarbon (diesel or gasoline). The first step is oils or fatty acids saponification by a metal hydroxide/oxide, which produces metal soap. When the raw material consists of fatty acids, it produces water as by-product, while glycerol is produced when using oil/fat. Then, diesel type hydrocarbons (green-diese) are obtained by the decarboxylation of metal soap, and biogasoline by pyrolysis. Metal hydroxide/oxide as a by-product of decarboxylation and pyrolysis is recycled to saponification material. The aim of this research was to investigate the effect of pyrolysis temperature of the basic soap 
of UFA on liquid product composition. In addition, a calcium-magnesium-zinc hydroxide combination to prepare the basic soap was designed.

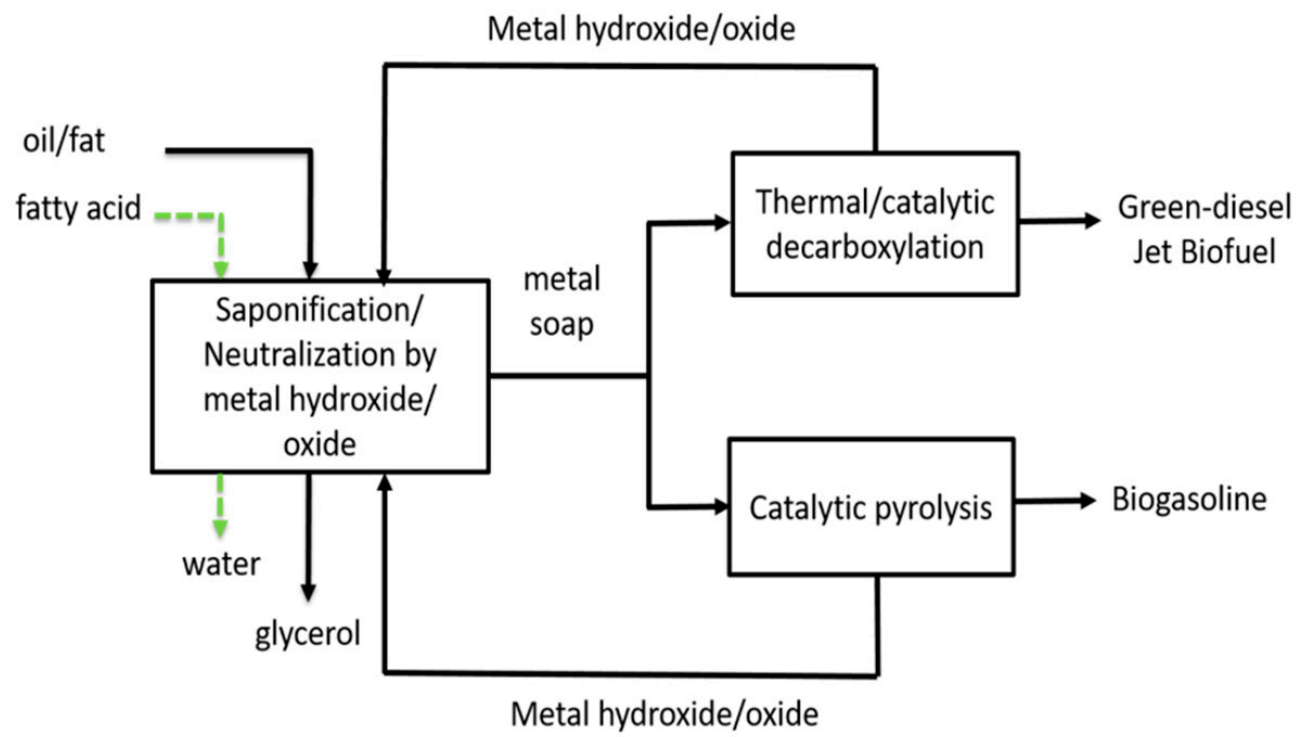

Figure 1. Flow diagram of biofuel production from vegetable oil/fatty acids.

\section{Methodology}

\subsection{Materials}

The unsaturated fatty acids were obtained from palm fatty acids distillate (PFAD) separation by the fractional crystallization method [30]. PFAD used in this research was received from PT Garmex Biofuel. Calcium chloride dihydrate $\left(\mathrm{CaCl}_{2}{ }^{\bullet} \mathrm{H}_{2} \mathrm{O}\right)$, magnesium chloride hexahydrate $\left(\mathrm{MgCl}_{2} \bullet 6 \mathrm{H}_{2} \mathrm{O}\right)$, and zinc chloride tetrahydrate $\left(\mathrm{ZnCl}_{2} \bullet 4 \mathrm{H}_{2} \mathrm{O}\right)$ were supplied by Merck and were used to prepare mix-metal hydroxide by co-precipitation with sodium hydroxide [31]. The Ca-Mg-Zn soap was obtained by a saponification reaction of unsaturated fatty acids with mixed metal hydroxide [32-34].

\subsection{Preparation of Unsaturated Fatty Acids}

The PFAD (100 g) was dissolved into $200 \mathrm{~g}$ of solvent A comprising 85\%-w acetonitrile with $15 \%-w$ of water at $55{ }^{\circ} \mathrm{C}$. The solution was cooled to room temperature while stirring. The precipitate was formed, filtered by vacuum funnel, and washed twice using acetonitrile solution. Furthermore, a precipitate which consisted of an unsaturated fatty acid was weighed and stored for iodine and saponification number analysis.

\subsection{Preparation of Mixed Metal Hydroxides}

The mixed metal hydroxide was prepared via the coprecipitation method of sodium hydroxide solution with high carbonates/nitrates base solution. The first burette (A) contains $50 \mathrm{~mL}$ of $0.1 \mathrm{~mol}(\mathrm{Ca}+\mathrm{Mg}+\mathrm{Zn})$ nitrate combination solution and the other burette (B) $50 \mathrm{~mL}$ of $0.2 \mathrm{~mol} \mathrm{NaOH}$ solution. The ratios of $\mathrm{Ca}$ to $\mathrm{Ca} / \mathrm{Mg} / \mathrm{Zn}$ mixture were chosen in the range of $15-85 \%$ by weight. The three metal inclusion points were expressed as $0.15 \mu$ and $0.50 \mu$ (mole ratios). The co-precipitation is controlled by the rate of drop burette $\mathrm{B}$ to keep the $\mathrm{pH}$ of slurry at 9.6. After continuous stirring for $30 \mathrm{~min}$, it was then separated by filtering and washing with water. Furthermore, the slurry was dried at $105^{\circ} \mathrm{C}$ for $12 \mathrm{~h}$.

\subsection{Preparation of Basic Soap}

The UFA $(0.1 \mathrm{~mol})$ and $0.05 \mathrm{~mol}$ of mixed metal hydroxide were fed into a saponification reactor while mixed. Then, the mixture was heated to $40-45^{\circ} \mathrm{C}$ before adding 
$4 \mathrm{~mL}$ of water and $0.18 \mathrm{~g}$ of formic acid $98-100 \%$ purity. The mixing was completed in at least $30 \mathrm{~min}$. Then, the basic soap was formed and dried at $60{ }^{\circ} \mathrm{C}$.

\subsection{Pyrolysis of Basic Soap}

The pyrolysis of the basic soap was performed in a $100 \mathrm{~mL}$ glass batch reactor equipped with two thermocouples for the liquid and vapor phases, a glass condenser, and a liquid product collector. A total of $10 \mathrm{~g}$ of the basic soap was added to the reactor. $\mathrm{N}_{2}$ gas flowed into the reactor for about $10 \mathrm{~min}$ to remove oxygen before it was heated to the specified temperature. The temperature variables were $375,400,425$, and $450{ }^{\circ} \mathrm{C}$ under atmospheric pressure for $3 \mathrm{~h}$. The gas product formed, condensed, and was collected in a liquid product collector. When the liquid product was formed, the uncondensed gas product was accumulated in a gas catcher which was installed in the liquid product collector. The pyrolysis liquid products were analyzed by GC-FID [1], while GC-TCD was adopted for the gas product. The pyrolysis apparatus was setup according to previous research [35].

\subsection{Measurement Values and Units}

The pyrolysis of mixed metal basic soap resulted in a series of products observed as periodic sets of peaks when analyzed by GC-FID. The GC-FID Shimadzu 2010 was equipped with a capillary column ( $\mathrm{rtx}-1)$ with flame ionization detector and dimensions of $30 \times 0.25 \times 0.25 \mu \mathrm{m}$. Sample (1 microliter) was injected into the GC by helium (the carrier gas) flow rate was $42.9 \mathrm{~mL} / \mathrm{min}$. The detector and injector temperature were $340{ }^{\circ} \mathrm{C}$. The following chromatographic temperature program was used for analysis: $40^{\circ} \mathrm{C}$ (at first)$300{ }^{\circ} \mathrm{C}\left(5{ }^{\circ} \mathrm{C} / \mathrm{min}\right)-340^{\circ} \mathrm{C}\left(1{ }^{\circ} \mathrm{C} / \mathrm{min}\right.$, constant $\left.45 \mathrm{~min}\right)$. The typical composition of UFA was obtained by PFAD separation and used as renewable feedstock in the saponification reaction analyzed by GC-MS.

The gas products of basic soap pyrolysis were analyzed by GC TCD Shimadzu type GC-8A. The sample was injected into the GC with argon (the carrier gas), the flow rate was $1: 3.5 \mathrm{~kg} / \mathrm{cm}^{3}$, and carrier gas flow pressure was $2: 3.5 \mathrm{~kg} / \mathrm{cm}^{2}$. The detector and injector temperature were $70^{\circ} \mathrm{C}$ and $50^{\circ} \mathrm{C}$. The qualitative information of oxygen functional groups or oxygenates in the liquid bio-hydrocarbon was analyzed using a Ferrox paper test [36].

\section{Results and Discussion}

\subsection{Unsaturated Fatty Acids and Mixed Metal Basic Soap Analysis}

The typical composition of UFA obtained by PFAD separation, which was used as renewable feedstock in the saponification reaction analyzed by GC-MS, is presented in Table 1. The result shows the total UFA content from PFAD separation of 9-octadecenoic acid $(59.9 \%$-wt) with 9,12-octadecadienoic acid (5.4\%-wt). Furthermore, based on data of PFAD shown Table 1, the UFA composition in the feed of PFAD 45.48\%-wt (C18:1 40.3\%-wt and C18:2 5.2\%-wt) means that UFA composition increased 19.9\%-wt. This indicated that separation of UFA from PFAD had gone well. The mixed metal basic soap of UFA from PFAD presented a saponifiable hydroxide value of $49 \%$, indicating a good soap from $50 \%$ as target. The basicity of soap was ascertained by detecting the O-H group through FTIR analysis. Figure 2 illustrates the FT-IR analysis of M-mix basic soap, showing the detection group O-H, C-H, C=C, dan C-C at wavenumber $3200-3700 \mathrm{~cm}^{-1}, 2800-3000 \mathrm{~cm}^{-1}$, $1500-1645 \mathrm{~cm}^{-1}$, and $1300-1500 \mathrm{~cm}^{-1}$, respectively [37]. The O-H groups indicate that it was basic soap and qualified as pyrolysis feed for biohydrocarbon production. The presence of groups detected in the soap matched the chemical formula of the basic soap: $\mu \mathrm{Ca}(\mathrm{OH})_{2} \bullet(1-\mu) \mathrm{Mg}(\mathrm{OH})_{2}{ }^{\bullet} \mathrm{Zn}\left(\mathrm{OOCC}_{17} \mathrm{H}_{33}\right)_{2}$. 
Table 1. GC-MS analysis of PFAD and UFA.

\begin{tabular}{ccc}
\hline Component & PFAD & UFA \\
\hline tetradecanoic acid (C14:0) & 1.7 & 3 \\
hexadecanoic acid (C16:0) & 40.2 & 17.6 \\
9,12-octadecadienoic acid (C18:2) & 5.2 & 5.4 \\
9-octadecenoic acid (C18:1) & 40.3 & 59.9 \\
octadecanoic acid (C18:0) & 7.8 & 5.3 \\
methyl 18-methylnonadecanoate & 1.3 & - \\
Octadecanoic acid, 10-oxo- & - & 1.9 \\
Methyl 10D-hydroxyoctadecanoate & - & 2.2 \\
others & 3.6 & 4.7 \\
\hline
\end{tabular}

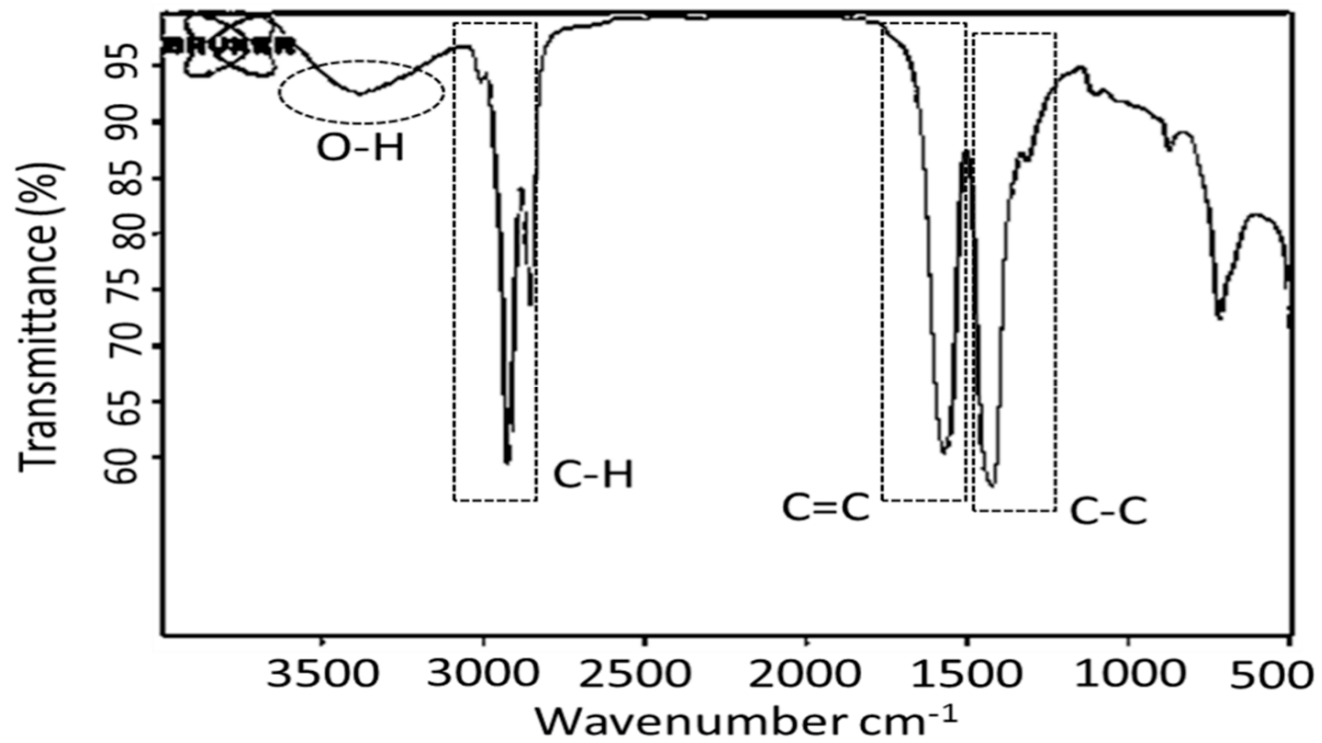

Figure 2. FT-IR of mixed-metal basic soap of unsaturated fatty acid.

\subsection{Identification of Product in the Liquid Fraction}

Table 2 presents material balance of biohydrocarbon products from the pyrolysis of M-mix basic soap, where liquid biohydrocarbon yield at $425{ }^{\circ} \mathrm{C}$ was $58.4 \%$-wt, higher than $375{ }^{\circ} \mathrm{C}(51.6 \%-w \mathrm{t}), 400{ }^{\circ} \mathrm{C}(55.9 \%-w \mathrm{t})$, and $450{ }^{\circ} \mathrm{C}(50.1 \%-w \mathrm{t})$. The phenomena observed could be explained at temperature pyrolysis above $425^{\circ} \mathrm{C}$, with the potential to accelerate cracking of high molecular weight hydrocarbon into low molecular weight hydrocarbon. The temperature trend was also reported by Neonufa et al. [38] in the decarboxylation of mixture metal stearin soap. Table 2 shows that the yield of liquid product increased with pyrolysis temperatures enhanced up to $425{ }^{\circ} \mathrm{C}$ and decreased by about $8 \%$-wt at $450{ }^{\circ} \mathrm{C}$. This can be explained as follows: at elevated temperature from $425^{\circ} \mathrm{C}$ to $450{ }^{\circ} \mathrm{C}$, the cracking of biohydrocarbon chains already obtained as a decarboxylation product has been expected. The result of this cracking is a shorter chain biohydrocarbon which could be condensed or not (as $\left.\mathrm{CH}_{4}\right)$. This is supported by Figure 6, which shows that at $450{ }^{\circ} \mathrm{C}$, the biohydrocarbon composition of the short carbon chain is highest compared to other temperatures. The result of this study is also supported by previous studies of [27] which reported that, at $450{ }^{\circ} \mathrm{C}$, all stoichiometric calcium decanoate soap obtained complete decarboxylation. Then, the soap begins to crack into shorter hydrocarbons chains and oxygenate compounds (aldehydes or ketone). The difference is that the liquid product in this study does not contain oxygenate compounds. This caused the pyrolysis feed to be basic soap, not stoichiometric. 
Table 2. Material balance of M-mix soap pyrolysis product.

\begin{tabular}{|c|c|c|c|}
\hline \multirow[b]{2}{*}{$\begin{array}{c}\text { Temperature } \\
\left({ }^{\circ} \mathrm{C}\right)\end{array}$} & \multicolumn{3}{|c|}{ Yield of Product (wt.\%) } \\
\hline & $\begin{array}{c}\text { Liquid } \\
\text { Bio-Hydrocarbon }\end{array}$ & Solid Residues & $\begin{array}{c}\text { Others } \\
\text { (Include Water and Gas) }\end{array}$ \\
\hline 375 & 51.6 & 20.7 & 27.7 \\
\hline 400 & 55.9 & 22.5 & 21.7 \\
\hline 425 & 58.4 & 23.7 & 17.9 \\
\hline 450 & 50.1 & 13.9 & 36.0 \\
\hline
\end{tabular}

The solid product of basic soap pyrolysis is a mixture of metal carbonates. The formation of the product indicates the phenomenon of the release of carbon dioxide ($\mathrm{COO}$ ) in basic soap. The pyrolysis reaction of basic soap is shown in Equation (1). Table 2 shows that the yield of solid product increases at $375-425^{\circ} \mathrm{C}$. This implies that the rate of -COO group removal increases with temperature. Furthermore, the yield of solid product decreases $\left(13.9 \%\right.$-wt) at $450{ }^{\circ} \mathrm{C}$. The plausible reason for this phenomenon is that at a temperature of $450{ }^{\circ} \mathrm{C}$ some of the metal carbonates have decomposed into metal oxide.

$$
\mathrm{M}_{\text {mix }}(\mathrm{OH})\left(\mathrm{OOCH}-\mathrm{C}_{7} \mathrm{H}_{15}-\mathrm{CH}=\mathrm{CH}-\mathrm{C}_{8} \mathrm{H}_{17}\right) \rightarrow 2 \mathrm{C}_{17} \mathrm{H}_{34}+\mathrm{M}_{\text {mix }} \mathrm{CO}_{3}
$$

Figure 3 shows that there are similarities in the peak chromatogram trend in all temperature variations. The pyrolysis of mixed metal basic soap produced a hydrocarbonlike mixture containing a carbon chain length between $C_{7}$ and $C_{20}$. The graph of the pyrolysis liquid product component (Figure 3 ) shows that liquid products of basic soap pyrolysis contain n-alkane, iso-alkane, and 1-alkene, while the most dominant component is iso alkane. This wide range of isoalkanes shows that, in addition to the decarboxylation reaction and cracking, the hydrogenation reaction was possibly followed by isomerization. A similar observation was made concerning oleic acid pyrolysis [39]. The identification of fatty acids in the liquid product of basic soap pyrolysis has been carried out at the lowest and highest temperature (Table 3). The analysis is in accordance with the AOCS CD 3D-63 method. The measurement shows that the liquid products of mixed metal basic soap pyrolysis have a low acid value, which means that the hydrocarbon-like fuel mixtures can be classified as biofuels. In addition, the ferox analysis for liquid product has also been performed, where an unidentified oxygenated compound was qualitatively observed. These results are different from the previous soap pyrolysis study [40]. The report shows that the liquid pyrolysis products of $\mathrm{Ca}, \mathrm{Mg}$, and $\mathrm{Zn}$ oleate soaps were detected in a carbonyl group $(\mathrm{C}=\mathrm{O})$. This led to the presence of fatty acids in the liquid pyrolysis product. This difference explains that the type of reactor and the feeding method used differ with this study. This study used a glass reactor with a batch feeding method, while previous studies adopted a stainless steel reactor and a semi-continuous feeding method.

Furthermore, the result in this study is also different from oleic acid pyrolysis research [39]. The report explained that the pyrolysis of oleic acids at $350-500{ }^{\circ} \mathrm{C}$ identified a series of fatty acids in the liquid product of oleic acid pyrolysis. This shows that the use of metals in this study succeeded in removing the -COO group in fatty acids. Furthermore, it proved that soap pyrolysis better than fatty acid pyrolysis to produce sustainable diesel. 

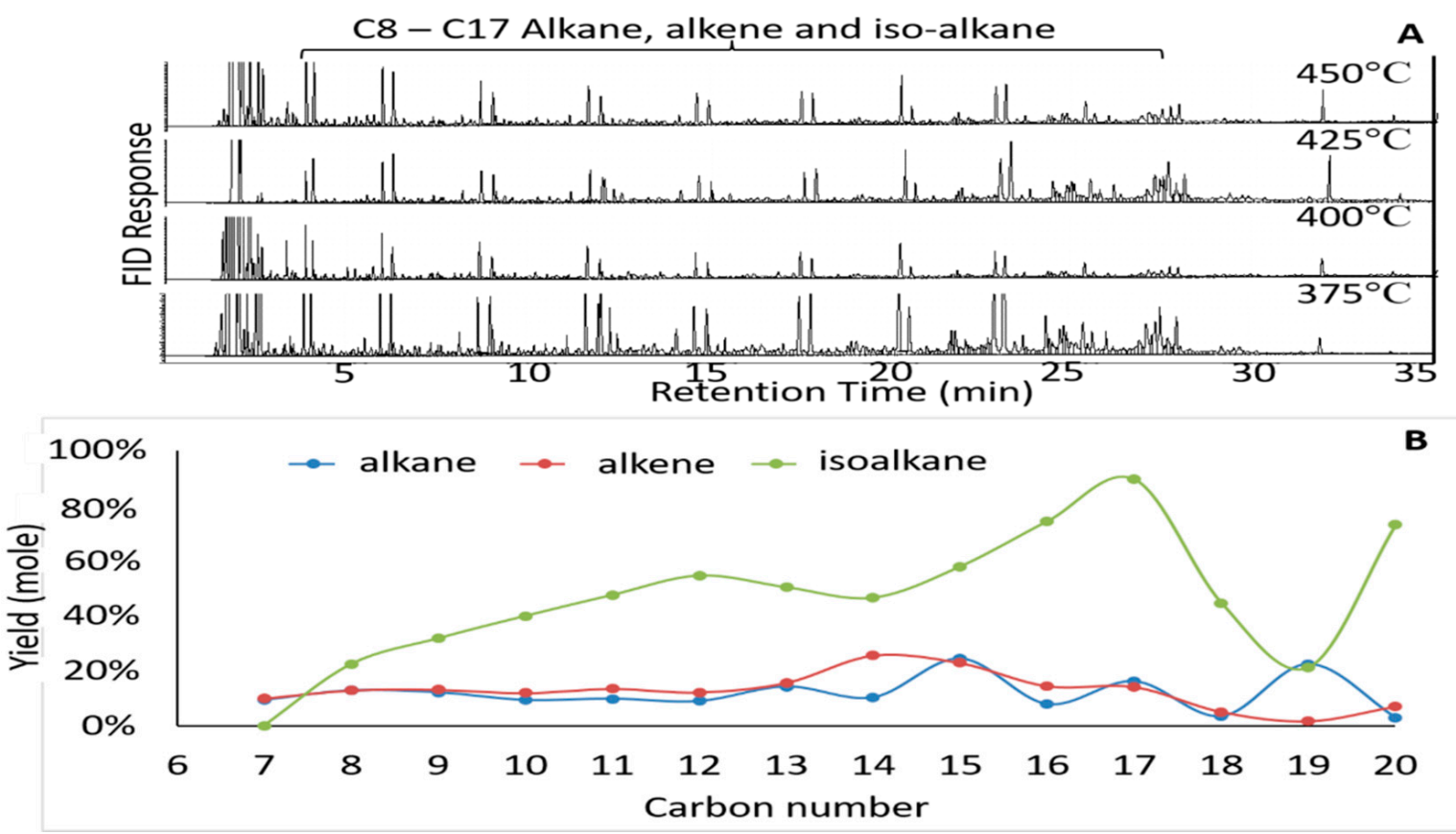

Figure 3. GC-FID chromatogram at different temperature (A) and hydrocarbon component of liquid products from pyrolysis of unsaturated fatty acid (B).

Table 3. Acid value of M-mix soap pyrolysis liquid product.

\begin{tabular}{cc}
\hline $\begin{array}{c}\text { Temperature } \\
\left({ }^{\circ} \mathbf{C}\right)\end{array}$ & $\begin{array}{c}\text { Acid Value } \\
\text { (mg KOH/100 g Sample) }\end{array}$ \\
\hline 375 & 0.66 \\
450 & 0.39 \\
\hline
\end{tabular}

\subsection{Effects of Temperature on the Composition of Alkane and Alkene Compounds in the Liquid Products}

Figure 4 shows the alkane and alkenes composition of the liquid product from mixedmetal basic soap pyrolysis at different temperatures and different $\mathrm{Ca} /(\mathrm{Ca}+\mathrm{Mg}+\mathrm{Zn})$ metal ratios. The yield of alkanes in liquid products reached a maximum $(25.9 \%)$ when the pyrolysis was carried out at temperature of $400{ }^{\circ} \mathrm{C}$. According to [41], when cracking occurs, a single bond on the side of the double bond will be cracked into two alkene compounds. Furthermore, alkenes undergo hydrogenation to obtain alkanes. Based on this mechanism, the yield of alkenes should be higher than alkanes, but not with this research. In this study, the amount of alkanes and alkenes at each temperature variation is almost similar. According to Neonufa [38], alkenes in biohydrocarbons are caused by other reactions than decarboxylation, namely the dehydration reaction of M-mix (oleic) $(\mathrm{OH})$ soap. The reaction produces dehydrated, partially M-mix (oleic) $(\mathrm{OH})$ soap and water. Then, the decarboxylation of the soap produces a mixture of alkane and alkene. When the amount of alkanes and alkenes is almost the same, the dehydration of basic soap coincides with the decarboxylation reaction. The next step is the hydrogenation of alkenes. The presence of hydrogen may be obtained from alkene decomposition with carbon as another product [39]. This was proven by the formation of black solid carbon after the pyrolysis. At pyrolysis temperatures from 375 to $400{ }^{\circ} \mathrm{C}$, the selectivity pathway towards alkane formation occurred. Meanwhile, at temperatures from $425^{\circ} \mathrm{C}$ to $450{ }^{\circ} \mathrm{C}$, the selectivity pathway towards the formation of alkene occurred. However, the selectivity trend is insignificant. 


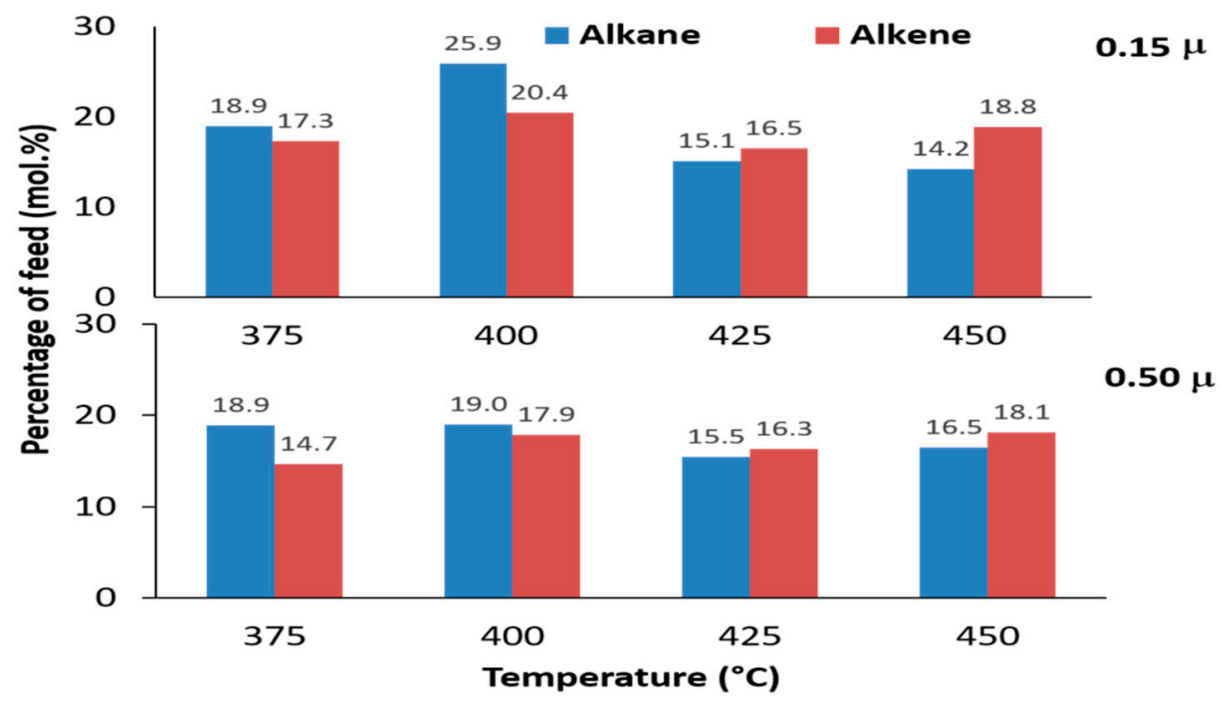

Figure 4. The n-alkane and 1-alkene composition liquid products from pyrolysis of mixed-metal basic soap at various reaction temperatures with two different Ca metal ratios $(\mu)$.

The data from Figure 4 show that alkene yields are almost similar for all temperature variations, averaging around $17.5 \%$. This fact is due to the batch feeding in this study, which causes the basic soap to heat slowly before reaching pyrolysis temperature. Then, the basic soap undergoes a relatively long decarboxylation time. According to Neonufa [38], high levels of alkenes in biohydrocarbons are caused by other reactions than decarboxylation, namely the dehydration reaction of $\mathrm{M}-\operatorname{mix}(\mathrm{oleic})(\mathrm{OH})$ soap. The reaction produces dehydrated, partially M-mix(oleic) $(\mathrm{OH})$ soap and water. Then, the decarboxylation of the soap produces mixture of alkane and alkene. Finally, the high level of alkenes are due to the dehydration of basic soap that occurs before or concurrently with decarboxylation. This result is supported by previous research [40] considering the effect of metal type on basic soap pyrolysis. The report showed that the semi-continuous pyrolysis of oleic $\mathrm{Ca}, \mathrm{Mg}$, and $\mathrm{Zn}$ basic soap, respectively, produce biohydrocarbons containing fewer alkene compounds. This indicated that, in pyrolysis with semi-continuous feeding, basic soap is more able to retain hydroxide than batch feeding before pyrolysis temperature.

\subsection{Effect of Temperature on Iso-Alkane Compounds in the Liquid Products}

The effect of temperature on iso-alkane compounds from liquid products is shown in Figure 5. At all temperatures, the liquid pyrolysis products had a higher amount of saturated products (n-alkane and iso-alkane) as compared to unsaturated products (alkene), where possible hydrogenation occurred after the pyrolysis. A similar observation was reported by Asomaning et al. [39] with n-alkanes as the main saturated product, whereas in this study the main product was iso-alkane (Figures 5 and 6). The observed difference was attributed to $\mathrm{Zn}$ used as a hydroxide mixture as a transition metal that could play a role in the isomerization of hydrocarbon as reported by Fontaine et al. [42]. The amount of iso-alkane at all temperatures was almost same. A reasonable explanation for this was related to the M-mix soap rupturing at temperatures below $400{ }^{\circ} \mathrm{C}$, forming carbonates and long chain hydrocarbon. Furthermore, the products were hydrogenated and partially isomerized. Isomerization products persist up to $450^{\circ} \mathrm{C}$. According to results of GC-TCD analysis of M-Mix soap pyrolysis gas products (Table 4), carbon dioxide and methane were also detected in the gas product. The previous study has described the formation of iso-alkane through decarboxylation and hydrogen transfer, respectively, from fatty acids. Based on the results shown in Figure 5, it can be noted that to produce a liquid product with the highest isomer product yield, the pyrolysis temperature must be $425^{\circ} \mathrm{C}$ as catalyst selectivity to isomerization products was influenced by the temperature. 


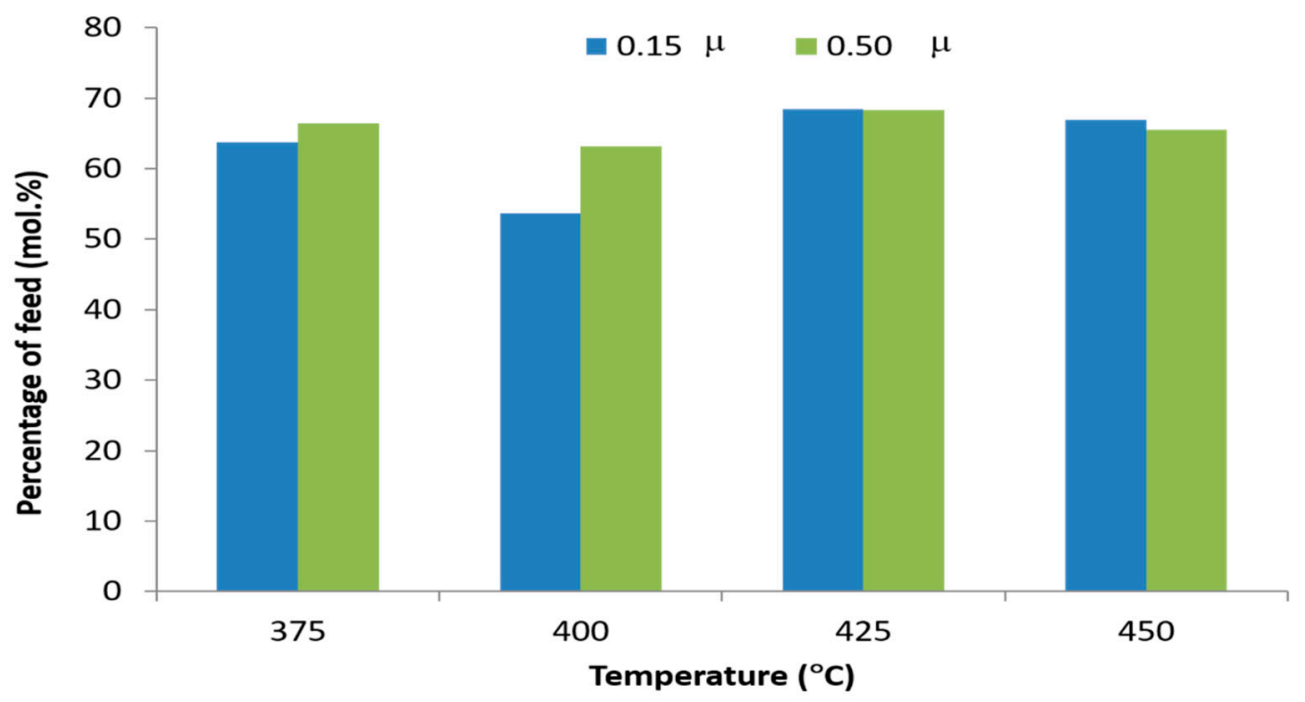

Figure 5. Iso-alkane composition of liquid products from pyrolysis of mixed-metal basic soap at various reaction temperature and with two different $\mathrm{Ca} /(\mathrm{Ca}+\mathrm{Mg}+\mathrm{Zn})$ metal ratios.

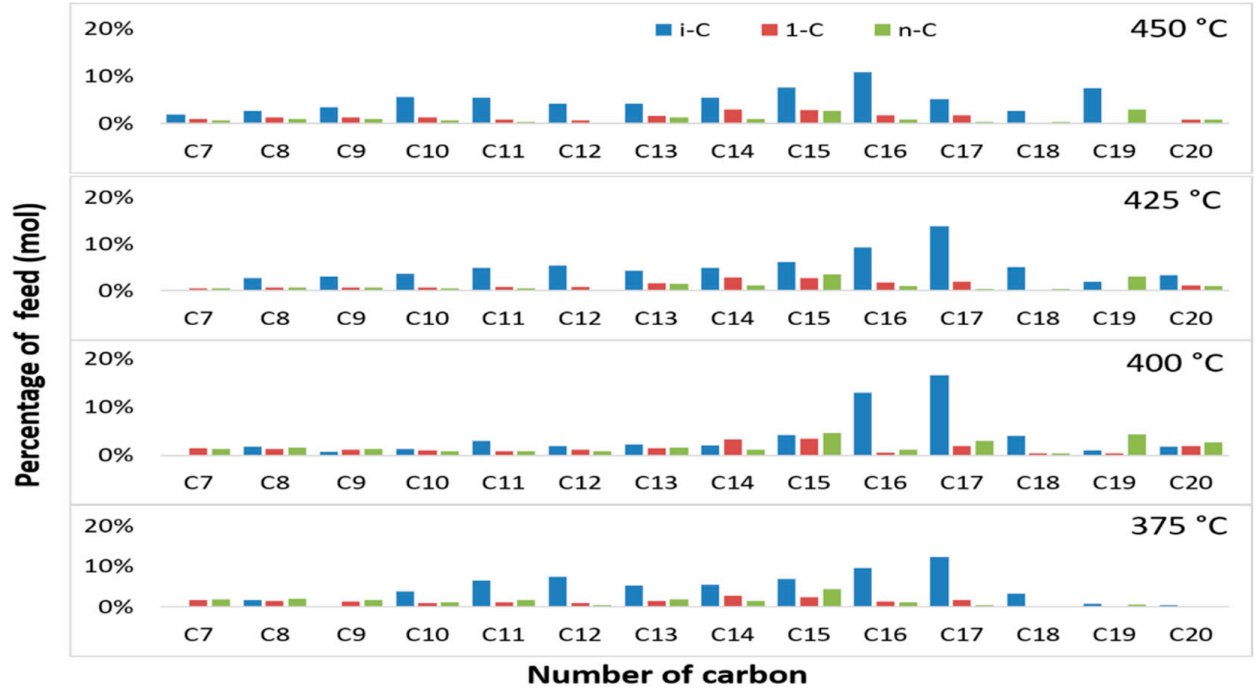

Figure 6. Compositions of hydrocarbons from pyrolysis of mixed metal basic soap at different reaction temperatures with $\mathrm{Ca} /(\mathrm{Ca}+\mathrm{Mg}+\mathrm{Zn})$ of $0.15 \mu$.

Table 4. Gc-TCD analysis result of M-mix soap pyrolysis gas product.

\begin{tabular}{ccccc}
\hline $\begin{array}{c}\text { Temperature } \\
\left({ }^{\circ} \mathbf{C}\right)\end{array}$ & $\mathrm{CO}_{2}$ & $\mathrm{CH}_{4}$ & $\mathrm{~N}_{2}$ & $\mathrm{O}_{2}$ \\
\hline 375 & $\sqrt{ }$ & - & - & - \\
425 & $\sqrt{ }$ & $\sqrt{ }$ & $\sqrt{ }$ & $\sqrt{ }$ \\
450 & - & - & $\sqrt{ }$ & - \\
\hline
\end{tabular}

The mixed metal basic soap has perhaps the most selective catalyst activity due to the isomerization at temperature of $425^{\circ} \mathrm{C}$. According to Masudi et al. [43], there are two methods to induce branch formation in hydrocarbons, namely (i) direct isomerization from saturated carbon and (ii) isomerization from unsaturated carbon, which is followed by hydrogenation. Figure 6 shows the hydrocarbons with different carbon numbers from the pyrolysis of mixed metal basic soap at various temperatures with a Ca metal ratio of $0.15 \mu$. The figure shows that iso alkanes are the dominant component of liquid biohydrocarbon products in almost all products with different numbers of carbon in all temperature variations. This component was the most dominant in $C_{16}$ and $C_{17}$. This shows that the pyrolysis 
of basic soaps began with decarboxylation. Referring to Table 1, the components of basic soap feed were dominated by oleic acids (9-octadecenoic acids), 60\%. Then, the decarboxylation of basic soap formed heptadecane (Equation (2)). After that, the hydrogenation of heptadecene formed heptadecane (Equation (3)), and heptadecane was isomerized (Equation (4)). This mechanism shows that the formation of iso alkane components in this study was attributed to the direct isomerization from saturated carbon.

$$
\begin{gathered}
\mathrm{C}_{8} \mathrm{H}_{17}-\mathrm{CH}=\mathrm{CH}-\mathrm{C}_{7} \mathrm{H}_{14}-\mathrm{CO}-\mathrm{O}-\mathrm{M}_{\text {mixed }}-\mathrm{OH} \rightarrow \mathrm{C}_{8} \mathrm{H}_{17}-\mathrm{CH}=\mathrm{CH}-\mathrm{C}_{7} \mathrm{H}_{15}+\mathrm{M}_{\text {mixed }} \mathrm{CO}_{3} \\
\text { Metal-oleic basic soap } \rightarrow \text { Heptadecene + Mixed-metal carbonate }
\end{gathered}
$$

$$
\begin{gathered}
\mathrm{C}_{8} \mathrm{H}_{17}-\mathrm{CH}=\mathrm{CH}-\mathrm{C}_{7} \mathrm{H}_{15}+\mathrm{H}_{2} \rightarrow \mathrm{C}_{8} \mathrm{H}_{17}-\mathrm{CH}_{2}-\mathrm{CH}_{2}-\mathrm{C}_{7} \mathrm{H}_{15} \\
\text { Heptadecene }+ \text { Hydrogen } \rightarrow \text { Heptadecane } \\
\mathrm{C}_{8} \mathrm{H}_{17}-\mathrm{CH}_{2}-\mathrm{CH}_{2}-\mathrm{C}_{7} \mathrm{H}_{15} \rightarrow \mathrm{i}-\mathrm{C}_{17} \mathrm{H}_{36} \\
\text { Heptadecane } \rightarrow \text { heptadecane isomers }
\end{gathered}
$$

\subsection{Effects of Temperature on Yield of Gasoline, Avture and Diesel Hydrocarbon Fractions}

The chosen operating parameters of pyrolysis, such as temperature, affect the quality of the liquid product, which mainly consisted of the fraction of hydrocarbon consisting of light fraction or $C_{7}-C_{11}$, moderate fraction or $C_{12}-C_{15}$, and heavy fraction or $C_{16}-C_{20}$. Figure 7 shows the effect of temperature on the yield of light, moderate, and heavy fractions of liquid product from the pyrolysis of mixed-metal basic soap. Based on the results shown in Figure 7, the yield of light fraction liquid product has an average around $20 \%$. Kaisha et al. [26] studied soap pyrolysis and found that the yield of gasoline or light fraction in the liquid product reached $25 \%$. This indicated that the pyrolysis products obtained in this study were in line with those reported by Kaisha et al. Nevertheless, the results of moderate and heavy fractions in this study were different than those reported previously. In this study, the moderate or jet fuel (avtur) fraction was 35\%, while Kaisha et al. reported $55-60 \%$. Moreover, the heavy or diesel fraction in this study was $45 \%$, while they reported in the range of $15-20 \%$. Other studies previously only reported the types of fractions in liquid products without a quantitative amount. This means that the yield of diesel fraction in this study is higher than previous research.

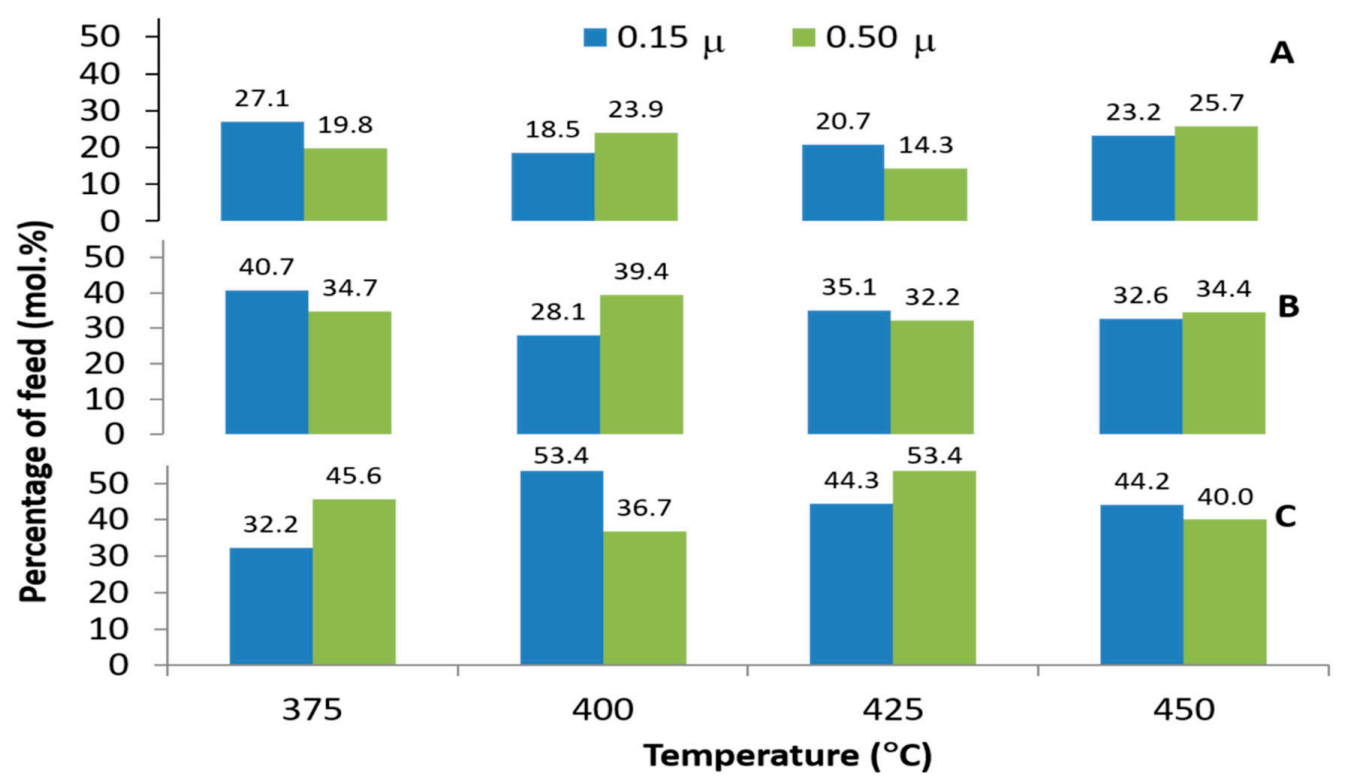

Figure 7. Gasoline $\left(C_{7}-C_{11}\right) /(A)$, Avture $\left(C_{12}-C_{15}\right) /(B)$ and diesel fraction $\left(C_{16}-C_{19}\right) /(\mathbf{C})$ product composition of mixed metal basic soap pyrolysis at different reaction temperatures and two different $\mathrm{Ca} /(\mathrm{Ca}+\mathrm{Mg}+\mathrm{Zn})$ metal ratios. 
Figure 7 shows that the highest yield of light fraction $\left(C_{7}-C_{11}\right) /$ gasoline was obtained at $375{ }^{\circ} \mathrm{C}(27.1 \%)$. This result is not supported by previous research where the optimal fraction was obtained when the temperature pyrolysis was higher. In addition, Asomaning [39] reported that the best raw material to produce biogasoline by fatty acid pyrolysis is unsaturated fatty acid. This could be explained as fatty acids cracked at pyrolysis temperature to form a shorter hydrocarbon chain, while at decarboxylation temperature, fatty acids removed the carboxyl group. This statement is supported by Shim [44]. The report shows that the deoxygenation of oleic acids in a hydrogen environment at $300{ }^{\circ} \mathrm{C}$ produced $\mathrm{C}_{9}-\mathrm{C}_{17}$ hydrocarbon compounds (diesel fuel range). The possible reason for the gasoline yield in this research, reached at $375^{\circ} \mathrm{C}$, is the long chain hydrocarbon from decarboxylation undergoing further decomposition [38]. This occurs due to the long time of pyrolysis, so that the basic soap evaporates and condenses back into reactor with high frequency. When this occurs continuously, the cracking also continues.

The data from Figure 7 indicate that the highest yield of avture fraction $\left(\mathrm{C}_{12}-\mathrm{C}_{15}\right)$ is reached at $375{ }^{\circ} \mathrm{C}(40.7 \%)$. This is supported by Hites and Biemann [27] as the metal soap cracked at above $400{ }^{\circ} \mathrm{C}$ produces shorter hydrocarbon compounds as the dominant product. Decarboxylation of metal soap occurs before metal soap cracking. The process removes the carboxyl group (-COO) from unsaturated fatty acids. The highest diesel fraction $\left(\mathrm{C}_{16}-\mathrm{C}_{19}\right)$ was reached at $425^{\circ} \mathrm{C}(53.4 \%)$. This shows that the long chain hydrocarbon remains in the pyrolysis liquid product above $400^{\circ} \mathrm{C}$. This result is not supported by previous research. This research showed that the best raw material to produce diesel fraction fuel by pyrolysis of fatty acids is saturated fatty acids [45]. A possible reason to explain this phenomenon is that the system used in this research is slow pyrolysis. In this pyrolysis, when the pyrolysis temperature has not reached $400{ }^{\circ} \mathrm{C}$, there is a liquid product drop in the liquid product flask. The liquid product contains a lot of long chain hydrocarbons mixed with liquid products that drop above $400{ }^{\circ} \mathrm{C}$. However, other researchers report that the pyrolysis of unsaturated fatty acids (oleic acids) at $450{ }^{\circ} \mathrm{C}$ also produced diesel-range hydrocarbon, although with a different catalyst [46].

\section{Conclusions}

Mixed metal basic soaps were converted to liquid biohydrocarbon by pyrolysis. The best yield (58.35\%) was obtained at $425^{\circ} \mathrm{C}$ with the higher diesel fraction of $53.4 \%$. No fatty acids were detected in the liquid biohydrocarbon. The pyrolysis of basic soap forces the metal to attract the - $\mathrm{COO}$ group on the soap to remove almost all of the group. This is the basic difference between basic soap pyrolysis and fatty acids. This proves that basic soap was a better feed for pyrolysis to produce sustainable diesel as compared to fatty acid feeds. The content of liquid product of basic soap pyrolysis is dominated by diesel range biohydrocarbons $\left(\mathrm{C}_{16}-\mathrm{C}_{19}\right)$. The product consists of normal alkane, alkene, and the various iso-alkane products.

Author Contributions: Conceptualization, S., A.I. and T.H.S.; methodology, M.P.; formal analysis, E.P., K., U.Z. and L.E.; investigation, E.P., K., U.Z. and L.E.; resources, H.D. and T.P.; writing—original draft preparation, E.P. and M.P.; writing—review and editing, E.P., O.M., Y.A.S., A.I.; supervision, T.P. and T.H.S.; funding acquisition, H.D. and T.P. All authors have read and agreed to the published version of the manuscript.

Funding: This research was funded by Program Penelitian Pengabdian kepada Masyarakat dan Inovasi (P3MI) at Institut Teknologi Bandung.

Institutional Review Board Statement: Not applicable.

Informed Consent Statement: Not applicable.

Data Availability Statement: Not applicable.

Acknowledgments: Not applicable.

Conflicts of Interest: The authors declare no conflict of interest. 


\section{References}

1. Neonufa, G.F.; Pratiwi, M.; Soerawidjaja, T.H.; Prakoso, T. High Selectivity of Alkanes Production by Calcium Basic Soap Thermal Decarboxylation. In Proceedings of the 24th Regional Symposium on Chemical Engineering (RSCE), Semarang, Indonesia, 15-16 November 2017; p. C-62.

2. Cardoso, A.R.T.; Conrado, N.M.; Krause, M.C.; Bjerk, T.R.; Krause, L.C.; Caramão, E.B. Chemical characterization of the bio-oil obtained by catalytic pyrolysis of sugarcane bagasse (industrial waste) from the species Erianthus Arundinaceus. J. Environ. Chem. Eng. 2019, 7, 102970. [CrossRef]

3. Ghosh, D.; Dasgupta, D.; Agrawal, D.; Kaul, S.; Adhikari, D.; Kurmi, A.K.; Arya, P.K.; Bangwal, D.; Negi, M.S. Fuels and Chemicals from Lignocellulosic Biomass: An Integrated Biorefinery Approach. Energy Fuels 2015, 29, 3149-3157. [CrossRef]

4. Lesmana, D.; Wu, H.-S. Pyrolysis of waste oil in the presence of a spent catalyst. J. Environ. Chem. Eng. 2015, 3 Pt A, $2522-2527$. [CrossRef]

5. Suchamalawong, P.; Pengnarapat, S.; Reubroycharoen, P.; Vitidsant, T. Biofuel preparation from waste chicken fat using coal fly ash as a catalyst: Optimization and kinetics study in a batch reactor. J. Environ. Chem. Eng. 2019, 7, 103155. [CrossRef]

6. Demirbas, A. Biofuels sources, biofuel policy, biofuel economy and global biofuel projections. Energy Convers. Manag. 2008, 49, 2106-2116. [CrossRef]

7. de Morais Araújo, A.M.; de Oliveira Lima, R.; Gondim, A.; Diniz, J.; di Souza, L.; Araujo, A.S. Thermal and catalytic pyrolysis of sunflower oil using AlMCM-41. Renew. Energy 2017, 101, 900-906. [CrossRef]

8. Naik, S.N.; Goudbc, V.V.; Routb, P.K.; Dalaib, A.K. Production of first and second generation biofuels: A comprehensive review. Renew. Sustain. Energy Rev. 2010, 14, 578-597. [CrossRef]

9. Quah, R.V.; Tan, Y.H.; Mubarak, N.; Khalid, M.; Abdullah, E.; Nolasco-Hipolito, C. An overview of biodiesel production using recyclable biomass and non-biomass derived magnetic catalysts. J. Environ. Chem. Eng. 2019, 7, 103219. [CrossRef]

10. Baladincz, P.; Tóth, C.; Hancsók, J. Production of diesel fuel via hydrogenation of rancid lard and gas oil mixtures. In Proceedings of the CHISA 2012-20th International Congress of Chemical and Process Engineering and PRES 2012-15th Conference PRES, Prague, Czech Republic, 25-29 August 2012.

11. Solymosi, P.; Eller, Z.; Hancsók, J. Motor fuel purpose hydrogenation of used cooking oils. Chem. Eng. Trans. 2013, 35, 1351-1356.

12. Keskin, A.; Gürü, M.; Altiparmak, D.; Aydin, K. Using of cotton oil soapstock biodiesel-diesel fuel blends as an alternative diesel fuel. Renew. Energy 2008, 33, 553-557. [CrossRef]

13. Onay, O.; Kockar, O. Slow, fast and flash pyrolysis of rapeseed. Renew. Energy 2003, 28, 2417-2433. [CrossRef]

14. Xu, J.; Jiang, J.; Lu, Y.; Chen, J. Liquid hydrocarbon fuels obtained by the pyrolysis of soybean oils. Bioresour. Technol. 2009, 100, 4867-4870. [CrossRef]

15. Yigezu, Z.; Muthukumar, K. Catalytic cracking of vegetable oil with metal oxides for biofuel production. Energy Convers. Manag. 2014, 84, 326-333. [CrossRef]

16. Biswas, S.; Mohanty, P.; Sharma, D. Studies on co-cracking of jatropha oil with bagasse to obtain liquid, gaseous product and char. Renew. Energy 2014, 63, 308-316. [CrossRef]

17. Mahari, W.A.W.; Zainuddin, N.F.; Chong, C.T.; Lee, C.L.; Lam, W.-H.; Poh, S.C.; Lam, S.S. Conversion of waste shipping oil into diesel-like oil via microwave-assisted pyrolysis. J. Environ. Chem. Eng. 2017, 5, 5836-5842. [CrossRef]

18. Chiappero, M.; Do, P.T.M.; Crossley, S.; Lobban, L.L.; Resasco, D.E. Direct conversion of triglycerides to olefins and paraffins over noble metal supported catalysts. Fuel 2011, 90, 1155-1165. [CrossRef]

19. Li, H.; Shen, B.; Kabalu, J.; Nchare, M. Enhancing the production of biofuels from cottonseed oil by fixed-fluidized bed catalytic cracking. Renew. Energy 2009, 34, 1033-1039. [CrossRef]

20. Idem, R.O.; Katikaneni, S.P.R.; Bakhshi, N.N. Thermal Cracking of Canola Oil: Reaction Products in the Presence and Absence of Steam. Energy Fuels 1996, 10, 1150-1162. [CrossRef]

21. Demirbaş, A. Biodiesel fuels from vegetable oils via catalytic and non-catalytic supercritical alcohol transesterifications and other methods: A survey. Energy Convers. Manag. 2003, 44, 2093-2109. [CrossRef]

22. Lappi, H.; Alén, R. Production of vegetable oil-based biofuels-Thermochemical behavior of fatty acid sodium salts during pyrolysis. J. Anal. Appl. Pyrolysis 2009, 86, 274-280. [CrossRef]

23. Santos, M.; Lourenço, R.; de Abreu, D.; Pereira, A.; de Castro, D.; Pereira, M.; Almeida, H.; Mâncio, A.; Lhamas, D.; da Mota, $\mathrm{S}$; et al. Gasoline-like hydrocarbons by catalytic cracking of soap phase residue of neutralization process of palm oil (Elaeis guineensis Jacq). J. Taiwan Inst. Chem. Eng. 2017, 71, 106-119. [CrossRef]

24. Hiebert, D.R. Decarboxylation and Hydrogenation of Safflower and Rapeseed Oils and Soaps to Produce Diesel Fuels. Ph.D. Thesis, Montana State University, Bozeman, MT, USA, 1985.

25. Joonwichien, S.; Duangchan, A. The study of preparation of biodiesel from pyrolysis of palm stearin and soap of palm stearin over catalyst. In Proceedings of the International Conference on Green and Sustainable Innovation, Chiang Mai, Thailand, 1 December 2006

26. Kaisha, N.G.K.K. A Method of Manucafturing Hydrocarbon Oils from Oils, Fats or Fatty Acids. U.S. Patent No GB175974, 1923.

27. Hites, R.A.; Biemann, K. Mechanism of ketonic decarboxylation. Pyrolysis of calcium decanoate. J. Am. Chem. Soc. 1972, 94, 5772-5777. [CrossRef]

28. Kufeld, S.E. Production of Diesel from Safflower Oil by a Soap-Pyrolysis Process. Ph.D. Thesis, Montana State University (MSU), Bozeman, MT, USA, 1 September 1988. 
29. Wenzel, R.N. Fatty Acids, Their Chemistry, Properties, Production and Uses. J. Am. Chem. Soc. 1961, 83, 4303.

30. Hoerr, C.W. Separation of Oleic Acid from Stearic and Palmitic Acids. U.S. Patent 2.705.723, 21 April 1951.

31. Zhao, R.; Yin, C.; Zhao, H.; Liu, C. Synthesis, characterization, and application of hydotalcites in hydrodesulfurization of FCC gasoline. Fuel Process. Technol. 2003, 81, 201-209. [CrossRef]

32. Hirsch, A.; Fleischer, E. Process for the Production of Basic Soaps of Divalent Metals in Powder Form. U.S. Patent 4.927.548, 22 May 1990.

33. Rogers, R.H.; Blew, W.R. Manufacture of Metal Soaps. U.S. Patent 2.890.232, 31 May 1956

34. McAskie, W. Ruminant Feedstuffs, Their Production and Apparatus for Use There. U.S. Patent 4.826.694, 2 May 1989.

35. Puspawiningtiyas, E.; Pratiwi, M.; Purwadi, R.; Istyami, A.N.; Elizabeth, L.; Prakoso, T.; Subagjo; Soerawidjaja, T.H. The effect of $\mathrm{Ca} / \mathrm{Mg} / \mathrm{Zn}$ mixing ratio on the research octane number of bio-gasoline during basic soap pyrolysis. Heliyon 2021, 7, 08314 . [CrossRef]

36. Pratiwi, M.; Muraza, O.; Neonufa, G.F.; Purwadi, R.; Prakoso, T.; Soerawidjaja, T.H. Production of Sustainable Diesel via Decarboxylation of Palm Stearin Basic Soaps. Energy Fuels 2019, 33, 11648-11654. [CrossRef]

37. Beis, S.; Onay, Ö.; Koçkar, Ö.M. Fixed-bed pyrolysis of safflower seed: Influence of pyrolysis parameters on product yields and compositions. Renew. Energy 2002, 26, 21-32. [CrossRef]

38. Neonufa, G.F. Drop-in Fuel Production Technology of Green Diesel and Bioavtur Type via Catalytic Thermal Decarboxylation of Basic Soap Base on Magnesium and Transition Metal Combination. Ph.D. Thesis, Institut Teknologi Bandung, Jawa Barat, Indonesia, 2017.

39. Asomaning, J.; Mussone, P.; Bressler, D.C. Thermal deoxygenation and pyrolysis of oleic acid. J. Anal. Appl. Pyrolysis 2014, 105, 1-7. [CrossRef]

40. Puspawiningtiyas, E.; Pratiwi, M.; Neonufa, G.F.; Purwadi, R.; Isyami, A.N.; Elizabeth, L.; Soerawidjaja, T.H.; Subagjo; Prakoso, T. Effect of metal type on basic soap pyrolysis produce bio-gasoline. IOP Conf. Ser. Mater. Sci. Eng. 2020, 823, 012027. [CrossRef]

41. Asomaning, J.; Mussone, P.; Bressler, D.C. Pyrolysis of polyunsaturated fatty acids. Fuel Process. Technol. 2014, 120, 89-95. [CrossRef]

42. Fontaine, M.F.; Riordan, M.D.; Jack, R. Treatment of Reformed Hydrocarbons with a Zinc Oxide-Zinc Chromite Catalyst. U.S. Patent 2.967.143, 3 January 1961.

43. Masudi, A.; Muraza, O. Vegetable Oil to Biolubricants: Review on Advanced Porous Catalysts. Energy Fuels 2018, 32, 10295-10310. [CrossRef]

44. Shim, J.-O.; Jeong, D.-W.; Jang, W.-J.; Jeon, K.-W.; Jeon, B.-H.; Cho, S.-Y.; Roh, H.-S.; Na, J.-G.; Ko, C.H.; Oh, Y.-K.; et al Deoxygenation of oleic acid over $\mathrm{Ce}(1-\mathrm{x}) \mathrm{Zr}(\mathrm{x}) \mathrm{O}_{2}$ catalysts in hydrogen environment. Renew. Energy 2014, 65, 36-40. [CrossRef]

45. Maher, K.D.; Kirkwood, K.M.; Gray, M.R.; Bressler, D.C. Pyrolytic Decarboxylation and Cracking of Stearic Acid. Ind. Eng. Chem. Res. 2008, 47, 5328-5336. [CrossRef]

46. Zhenga, Y.; Wanga, J.; Liua, C.; Lua, Y.; Lina, X.; Lia, W.; Zheng, Z. Efficient and stable Ni-Cu catalysts for ex situ catalytic pyrolysis vapor upgrading of oleic acid into hydrocarbon: Effect of catalyst support, process parameters and Ni-to-Cu mixed ratio. Renew. Energy 2020, 154, 797-812. [CrossRef] 